\title{
Diversification as a tool to increase energy security
}

\author{
Alena Bašová1
}

\begin{abstract}
The aim of this paper is to highlight the importance of diversification in the gas sector in Slovakia. We focus on defining the category of diversification, from the views we have received from foreign and domestic literature. The aim is to introduce individual approaches to the perception of energy security in its complexity. Its security affects all economic subsets at both transnational and national levels. Given the high capital intensity, it has become a problem not only for economic clusters but also for individual states. On a concrete example, we calculated the "price" of increasing security in the household sector under SR conditions.
\end{abstract}

\section{Key words}

diversification, energy security, price, capital intensity

J EL Classification: L0, O12, P3

Received: 4.10.2018 Accepted: 26.11.2018

\section{Introduction}

Natural gas has a significant strategic position in the energy market and has been provided for a long time by European sources as well as by imports from Russia. Such a relatively stable situation has been disrupted by gas crises starting from 2004, 2006 to 2009 (Duleba, A. 2009). At that time, import-dependent countries have perceived the urgency of diversifying transport routes in order to reduce the risk of falling supplies or completely shutting them down, especially when are secured from only one source(Bhagwat, 2011). Issues of safety of gas supply have become very urgent not only in terms of their practical security, but also in the context of serious discussions in academic circles as the flows of energy raw materials are the "arteries" of every economic system. The need for continuous and high quality provision of this commodity is an important assumption for the efficient functioning of each economy. The relationship between producers, distributors, suppliers and their customers determines relations across the whole production chain as it is a basic European, state, regional or local infrastructure, network(Stringer, 2018).

Countries that are heavily dependent on the import of this raw material can help increase their independence by creating sufficient reserves or efficient gas consumption. Gas trade requires a high level of interconnection between countries that are committed to building partnerships with several countries that have sufficient reserves. A barrier may be capital-intensive construction of transport routes, also affecting the geographical area through which these pipelines pass.

1 Ing. Alena Bašová, PhD, University of Economics in Bratislava, Faculty of National Economy, Department of Finance, Dolnozemská 1, 85235 Bratislava, e-mail: alenkabaso@gmail.com 


\section{Methodology}

In this paper we have used a variety of methods, from collecting information, especially from scientific works from both, foreign and home authors. Subsequently, we classified these knowledges into separate chapters. From the scientific methods we used mainly coupled methods of induction and deduction, analysis and synthesis and then we formulated partial conclusions. To better illustrate of the results obtained, we used graphical and mathematical methods, which are mainly used for the clear presentation of our results in tables and charts.

\section{Results and discussions}

In the article, we introduced several approaches from authors who originally defined energy security as part of state security, through finding its quantity at both transnational and national levels. The authors understand it in its complexity, in relation to other sectors of the national economy or the economic clusters of states, for example in the European Union. By using theory of comparative advantages, countries can jointly strive for security of supply, safety of transport routes in their regional space.

\subsection{Theoretical Approaches to Defining Diversification}

Since the Churchill Day's(Duleba,A.2009) declaration, the key to energy security is diversification (Stringer, 2008). The European region is more sensitive to "fluctuations" in the gas market compared to other regions. Its high dependence has been historically conditioned, because its need was mainly covered by European sources located in the Netherlands and Norway. Increasing demand requires an urgent need to diversify sources of natural gas. It causes the need to solve new strategies for finding potential partners and then building new links. For several decades, Russian gas was been an optimal and fully reliable source of natural gas. (Baláž, 2009) For both Russia and Europe, it was and still is a good agreement, as in Europe the demand for this commodity is still high, but the resources in its territory are considerably limited. On the other hand, Russia has enough reserves to cover own consumption European too. This relatively peaceful and beneficial relation for both sides had its lacks, which occurred in the form of gas crises in 2004, 2006 and 2009. In 2004 and 2006, Gazprom restricted gas supplies to Ukraine and Bulgaria. It was caused by price disagreements between Russia and these countries. The situation has sharpened in 2009 when tense financial and political relations caused a complete gas shutdown from Russia via the Bratstvo gas pipeline on Ukrainian territory. This situation led to the serious discussions about diversifying gas supplies and planning future transport routes that would provide energy security for gas consumers. To this situation has been expressed by Dr. Alex Pravda, whom is an expert on Russian politics at the University of St. Anthony in Oxford: "They know that they have the same dependent on us as we to them, if not more." He relied mainly on the fact that Gazprom in 2008 provided the state budget with an amount of about $20 \%$. This is a significant source of income for Russia. Gary Gastineau, director of the Exchange-Traded Funds 
Consultants (ETF), also deals with diversification. He sees diversification as "the creation of a portfolio that includes several measures to reduce risk." It stated an example in the financial field, but we can also applicate it on the gas market. If the planned investment includes only the shares of one company, it carries a high risk. We try to minimize the risk side and revenues maximizing. Mr Gastineau has characterized diversification in the financial sphere. Companies that trade with shares represent three types of diversification: diversification of source, transport and supplier (Stringer,2008). The shares represent the costs that countries "invest" in individual parts within the gas market. Even in the gas sector, the state obtains wider the broader base of natural gas sources, builds more transport routes and creates space for new entrants, its energy security and price stability will increase.

Diversification is one of the main pillars of energy security. We can consider it as so-called protection of countries against unpredictable threats from individual natural gas suppliers. Diversification itself contents of several elements, such as producers, network operators, suppliers, distributors of gas within aim to reduce risk of the country and find possible ways of alternative gas routes. Diversification can be achieved in two ways: diversification of the importing countries and diversification of transport routes (Yergin, Hillenbrand, 1982). Precise definition of the concept of energy security in the case of countries dependent on energy supplies is quite difficult in view of the absence of generally accepted definitions.

One of the experts on this issue is Daniel Yergin. He is perceived energy security as a reliable energy supply and access to energy resources in adequate amounts and at reasonable prices. Yergin emphasizes that the state in ensuring its energy security should base on several principles, namely: the diversification of supply of various raw materials, flexibility, market integration on raw materials and also the importance of the information. (Yergin, 2006). These targets include all aspects, by which the state is able to ensure its energy security. At the same time we try as well as a sufficient level of investment, creation of storage capacity and diversify supplies.(European Gas Market ,2008) Another author, L'ubomír L'upták, speaks about energy security as a impact of security, transit and use of existing or potential (alternative) energy sources on the environment and society. The energy security is perceived differently by different authors and it is the reason, why we can perceive as multidimensional view and it is possible to see from different perspectives. From a military point of view, energy security is the ability of the state to ensure the functioning of the essential components of the army in the event of a crisis. From an economic viewpoint in the case of countries dependent on energy supplies the attention is placed mainly on ensuring a adequate amount of energy required for economic growth and the availability of such energy at an acceptable price. (Belyi,2008). In our article, we will investigate energy security from a political point of view, at which energy security is perceived as a state's ability to ensure continuous availability of energy sources on the market for all consumers to ensure the well-being of the population. Given that, in this paper we will analyse the energy security from the perspective of a small country and we will concentrate on the analysis to secure supply of natural gas and other energy sources. We will energy security characterize as the ability to ensure the stability of supply for all consumers and adequate level of diversification of such supplies. When we energy security adopted as as an important part of national security, we can explain in accordance with the principles of the Copenhagen 
School was developed within the realistic theory. The Copenhagen School does not perceive security threats as a direct impact lack of resources, but rather as the result of political interpretations of the threat by security process. (McSweeney,1996). In the case of the Copenhagen school can be analysed energy security as Theory complex regional security (RSCT). Regional energy security complexes are formed through the interaction between two or more States in limited geographic area which includes the relationship of energy dependency of these countries and the perception of this dependence as a threat. This interaction includes energy sources trading in whole production chain, from their production (export), purchasing (import) and transportation of energy. (Gloystein, 2017)

This dependence has increased, because through Slovak territory flows approximately $2 / 3$ of the total volume of natural gas, which flows into EU. Russia wants to circumvent the territory of Ukraine and to supply the natural gas by other routes due to financial disagreements. One of the ways how it could possible to reduce dependence Slovak Republic from the Russian Federation and thereby increase our energy security is diversification of supplies. Through diversifying energy supplies raw materials we can reduce the risk of lack of the necessary volume of raw materials in case of failure their supplies from a single source as well as acquire new possibilities for sufficient energy supplies to increase their energy security. We can adopt three possible scenarios: the diversification of energy resources, diversification of countries from which these raw materials flow as well as the diversification of transport routes (Baumol, - Bailey, - Willing, 1977). Diversification of energy resources means that the country should seek for greater possible diversity in the field of energy raw materials used, thus, to try to reduce their dependence the only source. It is necessary to increase the number of countries from which the needed source can be imported. This type of diversification is oriented on increasing of the number of sources, which reduces dependence from the one sources of energy raw materials. Diversification of transport routes means increasing the number of routes, which are going to the country, which is important for lowering the risks of transit states.

Souleiman specifies diversification as a way of reducing or the layout the risk if deliveries fails or if the only one source is shutdown. However, the problem is the limited number of suppliers for European Union countries (hereinafter EU).( Jambor ,2009) The issue of country interdependence is closely related to diversification, with the authors Richard Rosecrance and Arthur Stein defining it as the interrelationship between countries, bringing both advantages and disadvantages. The basic principle is to compare the advantages of one country A in relation to another country B. (Rosecrance, Stein, 2017) Country A focuses only on the production of those products that are profitable for it sale them at lower costs than in country B. On the other hand, it imports the goods it produces with relatively high costs. In resolving the question of interdependence, the authors point to two alternatives. The first is to create a relatively equally advantageous relationship of country A with other C, D countries, too, so that A country "protects" itself in case of disturbing good relations with the original country B. Subsequently, the participants will rather try to find a compromise on the arisen disputes. The second possibility is the orientation and focus on the self-sufficiency of the national economy. This path is perhaps only a theoretical example in today's globalized world and with the limited resources. Cooperation and integration of the gas market is also supported by 
Fabian Wigand, who is the lead consultant for Ecofys in Berlin. (Wigand,2013) He appeals the EU member states to integrate their gas systems more closely so that they do not focus on finding expensive solutions on their own territory but to prefer globalization that would bring a risk spreading of several countries, and that would lead to a safer system.

\section{Analysis of the natural gas market}

Natural gas is a relatively cheap and clean energy source that is environmentally friendly. In the long term it is projected $2 \%$ annual increase in demand of natural gas in all regions of the world.

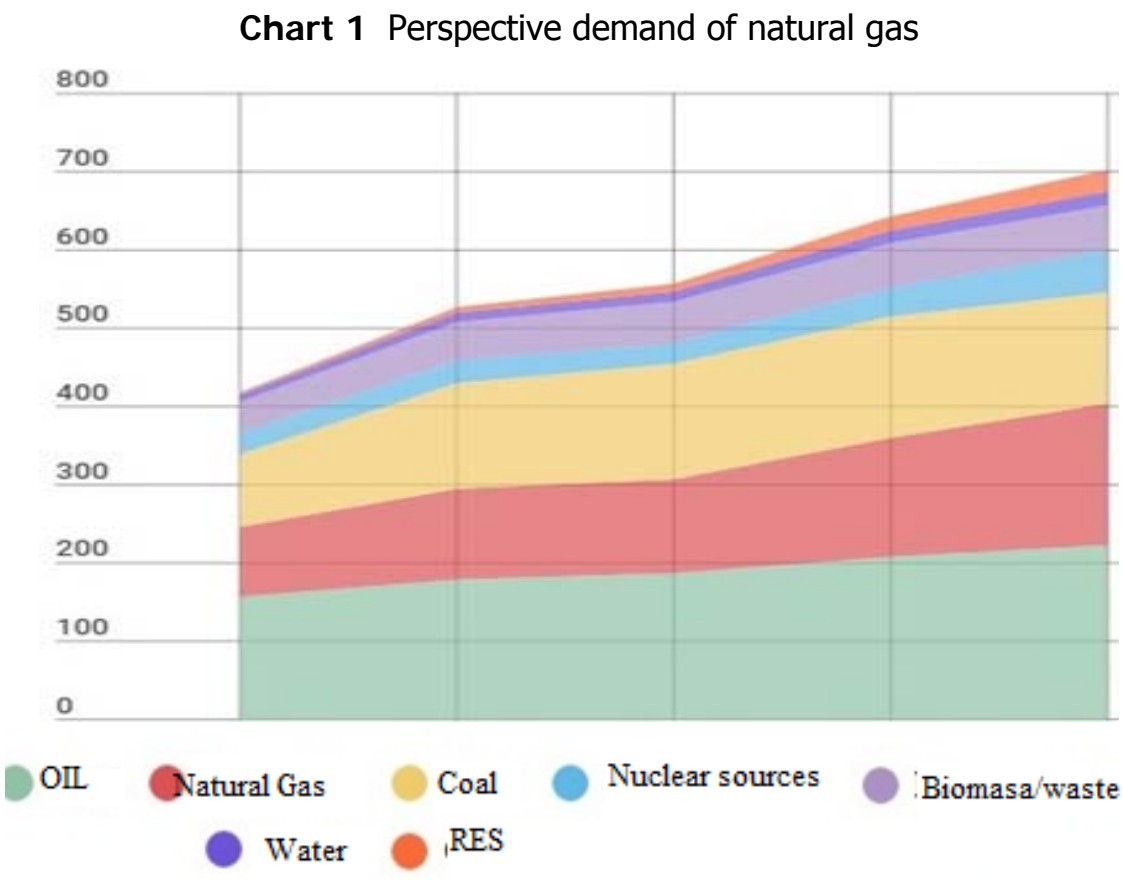

Source: own processing according: Outlook for Energy, 2017

This development supposed that natural gas in 2040 will be placed at the leading places of fossil sources. It is a way to minimize the carbon dioxide and thereby improve the quality of air.

The six largest natural gas producers, according to the information available on the International Gas Union (IGU) web site, these countries are officially stated for the year 2016 as the biggest producers. (in billions of cubic meters of bcm).

From the chart above, we can conclude that the US is the largest natural gas producer (and consumer) in 2016, despite the fact that its production has fallen by $2.27 \%$ compared to the previous year. (Pitatzis, 2016). 
Chart 2 Production of natural gas in 2016(bcm)

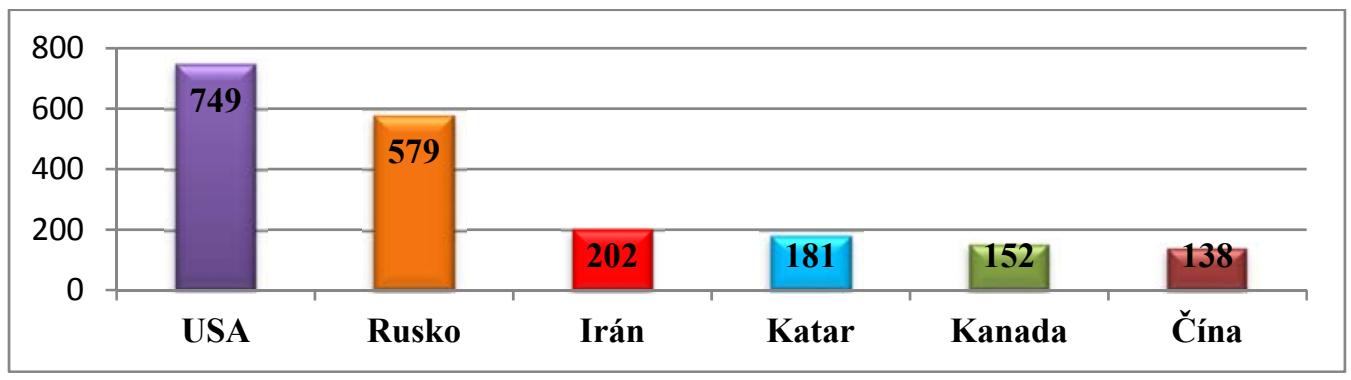

Source: Own processing by IGU

An important role in ensuring European gas supplies is played Norway. Due to its favourable geographic location and adequate natural gas reserves, it is a reliable gas supplier to Europe. The Cedigaz International Natural Gas Association states that Norway has exported approximately 110 billion cubic meters of natural gas to Europe, which is $21 \%$ of total European demand.

A suitable alternative is, for example, the use of liquefied natural gas(hereinafter LNG)( Pitatzis,2017) Demand for natural gas is not uniform in the year, and to building underground gas storage is one tool as provide continuous supply during year. Storages are filling in summer when offer exceeds demand and the gas purchase price is advantageous and free shipping capacity yare favourable, too. Use of LNG is increasingly mentioned, but most of the terminals are situated in Western Europe. The European Union's goal is to remove this shortcoming by building additional 24 LNG terminals in the South East region, particularly in Italy, Greece, the Western Balkans and the Baltic countries.

Picture 1 Types of European LNG terminals

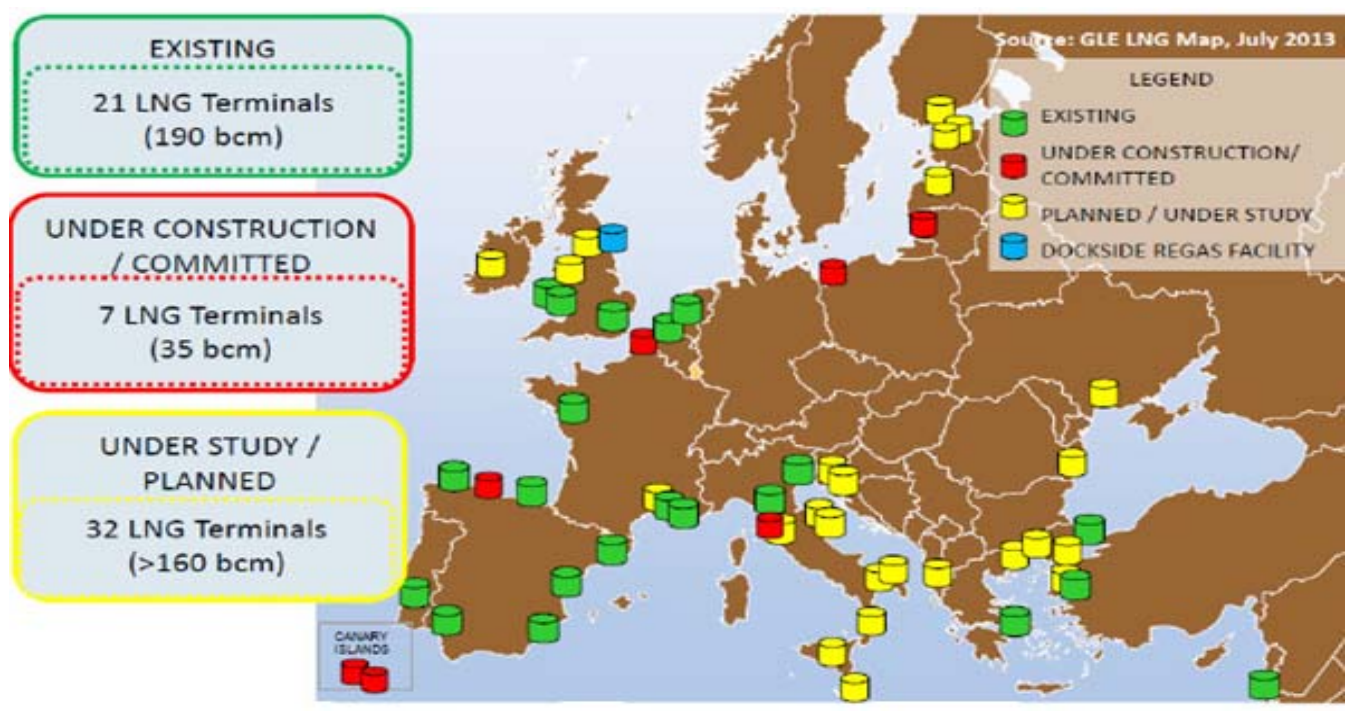

Source: www.eia.com 
Europe needs to make greater efforts to diversify its gas resources, possible solutions are imports of LNG from America, opening of the southern corridor to transport natural gas from Azerbaijan and later also from Iran and Turkmenistan to Europe, newly discovered natural gas deposits in the Eastern Mediterranean, LNG imports from Africa or other suppliers - such as Qatar and Australia. (OECD/IEA. World Energy Outlook 2017)

Chart 3 Main exporters of LNG in 2016

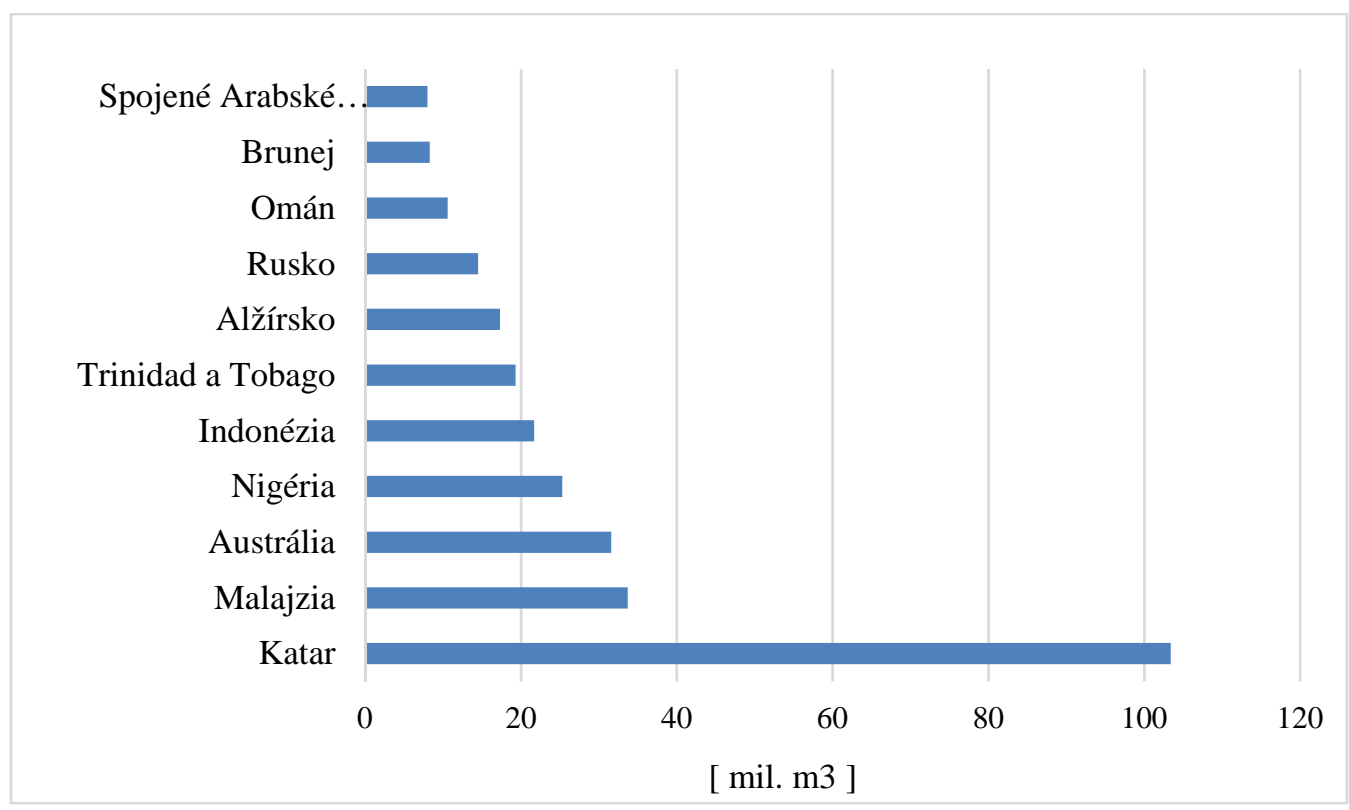

Source: Own processing by: https://iakal.wordpress.com/2015/10/30/largest-Ingexporters-indonesiavsmalaysia/

Since 2005, the Western Classical Markets have developed a gas exchange trading model that is very fast. When the shares price is low, the gas is bought and filled in the undeground storages. When the gas price increases, the gas is preferably delivered to the stock market. Spot markets are currently the most advanced trading tools. An important company with underground storages is Nafta, a.s., which has, of course, its traditional clients - energy companies, as well as new customers, which arised from the gradual liberalization of the market and become traders. The second part of customers are traders who speculate on gas exchanges. NAFTA has in its portfolio of clients all the traditional players operating in Slovakia, but the company also has a fairly significant number of foreign clients who use the storage for the suppling of gas to Baumgartenhub and markets in Germany, France, Italy or Switzerland. In terms of storage capacity utilization of natural gas of all operators in Slovakia can say that the capacity at the Slovak market are sufficient. It is interesting that about half the storage capacity in operation of NAFTA is intended for export. For Slovakia, which is highly dependent on imports of energy resources and the storage capacity is one of the few products in the field of energy that we can export. 
Picture 2 Undrerground storages in connection of LNG

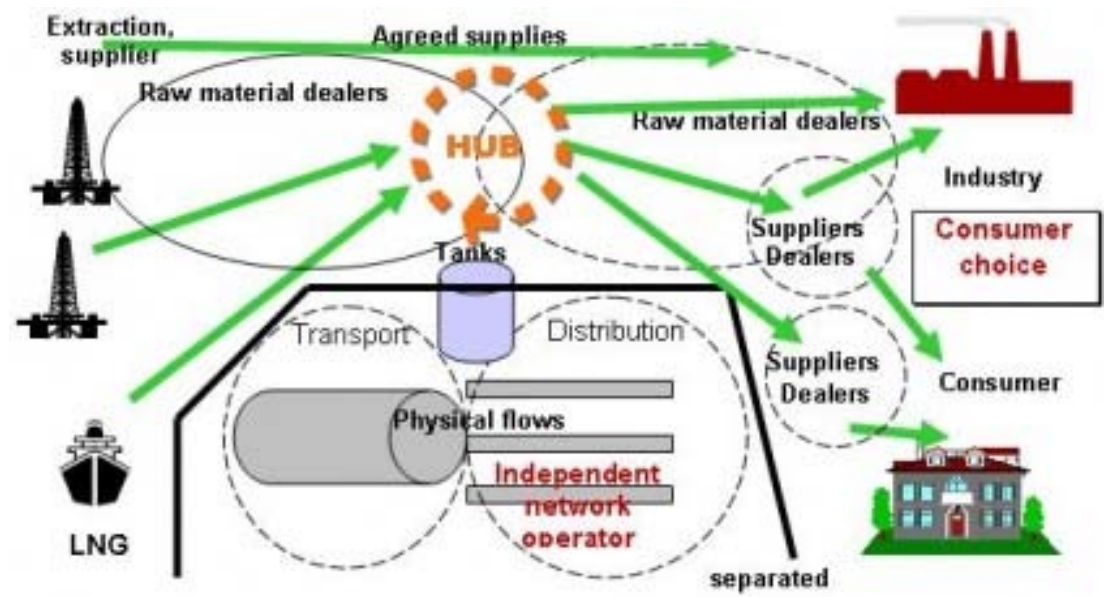

Source: own processing according: www.jstor.org

The main form of LNG transport is import by sea in order to match the demand for natural gas in selected EU countries. While in 2007 world LNG production was 230 billion cubic meters (hereinafter m3), in 2015 it was already 333 billion m3. By 2019, growth is projected to be at least 450 billion cubic meters. The average distance of its delivery in 2015 was $14,260 \mathrm{~km}$, what it took 16 days. LNG is a form of condensed, ecological energy that can be transported over long distances. Next table provide us tips go Hubs.

Table 1 Tips of natural gas hubs

\begin{tabular}{|l|l|}
\hline Trading Hubs & $\begin{array}{l}\text { Hubs, which are considered stable place of business and have } \\
\text { achieved a certain degree of implemented business contracts. } \\
\text { They are open and accessible points to large number of partici- } \\
\text { pants with a virtual character. For example, American Henry } \\
\text { Hub, British NBP and Dutch TTF. }\end{array}$ \\
\hline Transit Hubs & $\begin{array}{l}\text { They allow the transport of large volumes of natural gas for } \\
\text { further transported. Significant are the Austrian Baumgarten } \\
\text { and the Belgian Zeeburge. }\end{array}$ \\
\hline Transition Hubs & $\begin{array}{l}\text { Transitions Hubs are virtual points have not yet reached a cer- } \\
\text { tain degree of advanced business. These include German } \\
\text { Gaspool and NCG. }\end{array}$ \\
\hline
\end{tabular}

Source: own processing according: Heather,P

\section{Energy safety}

The new concept to energy safety is concentrate on to ensure a smooth and reliable supply of natural gas in adequate volume and for all segments of customers. In contrast with the previous tradition, the indicators do not provide measurable indicators. It focuses on making transparent and informed decisions in five different stages of the 
energy security assessment, with aim to ensure a safe and reliable supply of natural gas in a adequate volume and for all segments of customers, it is important to monitor conditions of supplies from point of view of ensuring:

- Balance of supply of natural gas and demand and consumption of gas,

- The levels of expected future gas consumption and available supplies,

- Anticipated and planned transport, distribution and storage capacities, measures to cover peak natural gas consumption.

The main component and program for the further development and implementation of energy security are focused on how to make transparent and informed decisions in five different stages of the energy security assessment. As shown next scheme, access to energy systems helps to make informed decisions at each stage of the evaluation.

Scheme 1 Generic versus specific approach to energy safety

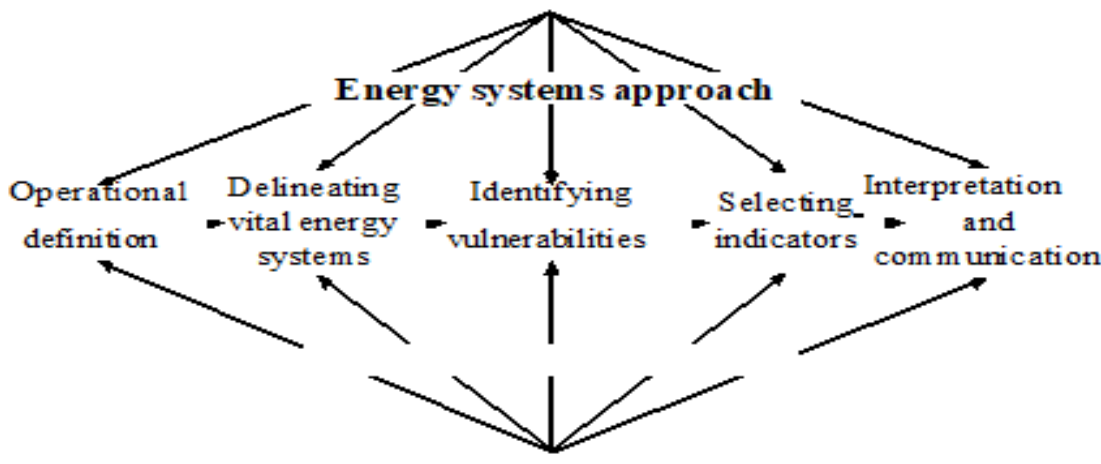

Source: own processing according: International Handbook of Energy Security.

The first part reflects the idea that energy security is the same in perceptions as in the reality of energy system. ( Dyer, -Trombetta, 2013)

The second set of options states the fact that energy security is a highly contextspecific system. A good evaluation of decisions will strike the right balance between these main options at each of the five phases.

- In the first phase, a definition of energy security will be chosen, which will be acceptable for the evaluators and will be sufficiently functional with respect to all the energy systems analysed.

- The second phase defines vital energy systems. These are important for all benchmarks, political interests and the security of real energy flows.

- $\quad$ The third phase identifies the vulnerabilities of these vital energy systems. Existing energy policy concerns are a good starting point, but human perceptions of risk may be heightened. We should reduce this bias by an objective analysis of all components of safety.

- In the fourth phase, energy security indicators are selected that reflect (but do not necessarily measure) identified vulnerabilities or possible risks. It is usually easier to start with metrics indicators. Second reason expresses typically, data 
for these measurements will be available. It may seem complicated that we want to get a vulnerability indicator using for calculations and indicators. Such a complex indicator will require more effort for interpretation and discussion. These indicators are relevant to a choiced situations. They should also be comparable for all the situations covered by the assessment.

- In the fifth and final phase, the indicators are interpreted and presented in a form that facilitates the response to the initial safety assessment issues. This interpretation can either be in the form of composite indexes or qualitative evaluations.

- $\quad$ One of the first energy security experts is Daniel Yergin. Thesimple formulation states Daniel Yergin whom energy security is defined as sufficient supplies provided energy with affordable prices. (Yergin, D. 2006) He has extended this definition on dimension of energy security; he reacted to answer increasing tensions on the global market for energy resources, the impact of various natural disasters, technical failures and attacks on energy infrastructure. He also responds to various market speculations, political instability and numerous other internal and external factors influencing the current energy security. Yergin defines four basic principles to secure of the energy safety.

- The first principle is traditionally diversification, access to alternative sources reduces the risk of ensure continuous supplies of energy raw materials.

- $\quad$ For creating a flexible system Yergin emphasizes the need for strategic reserve, reserve production capacity, back - up systems along the production and distribution chain. In this context, now comes to the fore underground gas storage facilities.

- $\quad$ The third principle is the recognition of integration.

- The fourth principle is the need and importance of the information. This principle is based on experience. Precise definition of the concept of energy security in the case of countries dependent on energy supplies is difficult in view of the absence of generally accepted definitions. One could however be said that the definition of energy security for countries importing energy commodities most often consist of three aspects:
A Adequate quantity of energy raw materials
$B$ Adequate form
C Adequate price (Yergin,2006).

\section{Calculation of energy security in Slovak republic}

The EU is currently seeking diversification of transport routes, is oriented on NorthSouth gas pipelines. "In general, gas pipelines are built only when the long-term contracts have been secured," said Peter Fox-Penner, an expert on economic, regulatory and strategic questions in network industries. The aim of implementing a North-South project is to connection of Baltic Sea with southern European waters in the Aegean, Adriatic, Mediterranean and Black Sea. The result should be diversification of transport links and higher stability of gas supplies not only for this region but also for the entire European continent. The following countries cooperate on the project: Italy, Cyprus, 
Austria, Bulgaria, Slovakia, the Czech Republic, Germany, Poland, Greece, Hungary, Romania and Slovenia. The North-South Corridor will allow the transport of natural gas from Swinoujscie in Poland to port Omišalj in Croatia.( Polkinghome, 2016) At present, some of its parts are in operation, such as the interconnection of Slovakia and Hungary near the Szada Hungarian village or the Polish gasification terminal at Swinoujscie port. By implementing thisprojects, the Central European countries will ensure better interconnection for a more liquid and competitive gas market, with increasing stability and security of supplies to the participating countries. (Gloystein, 2017)

Map 1 Map of planned north-south connection

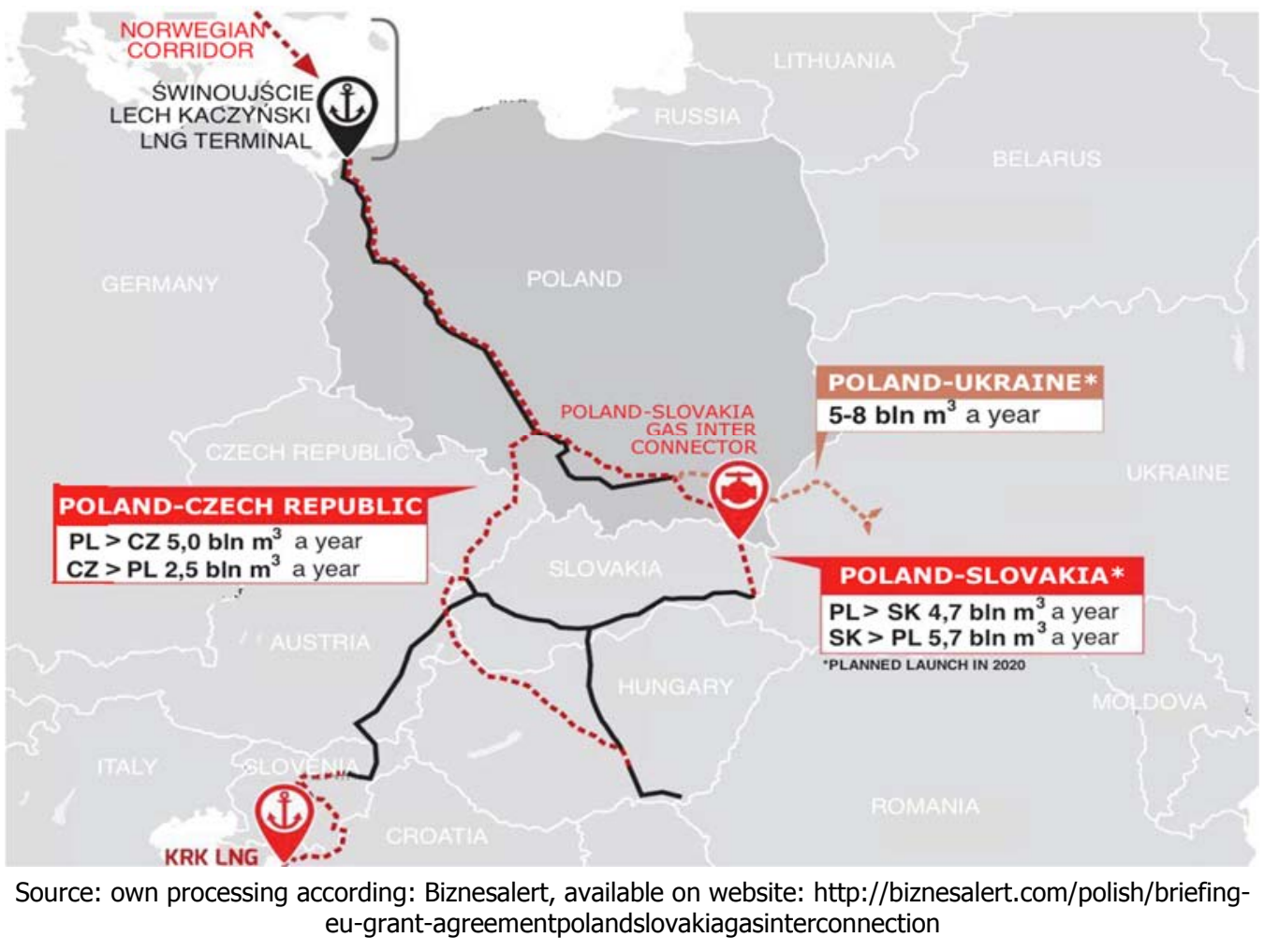

Next important project is Eastring project; the survey will focus on economic, technical and environmental analyses and should be known in June 2018. Implementation will be carried by the Slovak company Eustream, a.s. and the Romanian company Transgaz S.A. The building work could begin in 2020; with the expected end of construction being in 2024. The calculation of increased security will be applied only in the Slovak household sector. The household is defined in Slovakia as a individual person, persons who enter into an agreement with the supplier of the quantity of consumed natural gas.

The contract also specifies the type of tariff to which the household belongs. In accordance with the Decree of the Office for Regulation of Network Industries (hereinafter RONI )no. 223/2016 Z. z. households in the territory of the Slovak Republic from 
01.01.2017 are divided into new groups according their consumption of gas. In the next table we also state current and the previous tariff breakdown.

Table 1 Overview of individual household tariffs since 2017

\begin{tabular}{|c|c|c|c|}
\hline $\begin{array}{l}\text { Tariff group valid } \\
\text { from } \\
01.01 .2017\end{array}$ & $\begin{array}{l}\text { Tariff group } \\
\text { valid to } \\
31.12 .2016 \\
\end{array}$ & kWh & $\mathbf{m}^{3}$ \\
\hline T1 & $\mathrm{D} 1$ & $<0,2138 \leq$ & $<0,200 \leq$ \\
\hline T2 & D2 & $<2138,18173 \leq$ & $<200-1700 \leq$ \\
\hline T3 & \multirow{2}{*}{ D3 } & $<18173,42760 \leq$ & $<1700-4000 \leq$ \\
\hline T4 & & $<42760,69485 \leq$ & $<4000-6500 \leq$ \\
\hline T5 & \multirow{4}{*}{ D4 } & $<69485,85000 \leq$ & $<6500-7951 \leq$ \\
\hline T6 & & $<85000,100000 \leq$ & $<7951-9355 \leq$ \\
\hline 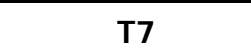 & & $<100000-300000 \leq$ & $<9355-28064 \leq$ \\
\hline T8 & & $<300000-641400 \leq$ & $<28064-60000 \leq$ \\
\hline
\end{tabular}

Source: own processing according: Decree č. 223/2016 Z.z. ÚRSO

Under the SR conditions, the commodity price for households is composed of the item weighted average of year consumption created on the European Energy Exchange (EEX) in Leipzig, Germany, representing 30\% and an additional $70 \%$ derived from prices agreed in long - term contracts between SPP, as and the Russian giant Gazprom. At present, the final gas price is comprised of the Total Fixed Monthly Rate and the Total rate for gas consumed. In line with all the above information, including the regulated, unregulated components and current charges, we will present in next table the current maximum prices set by the URSO, which are binding on the target household group from 01.01.2017.

Table 2 Maximum gas rates of final prices of households with VAT since 2017

\begin{tabular}{|c|c|c|}
\hline Tariff & $\begin{array}{l}\text { Total fixed monthly rate } \\
(€ / \text { month })\end{array}$ & $\begin{array}{l}\text { Total rate for gas consumed } \\
(€ / \mathrm{kWh})\end{array}$ \\
\hline 1 & 2,35 & 0,0521 \\
\hline 2 & 6,91 & 0,0390 \\
\hline 3 & 10,37 & 0,0372 \\
\hline 4 & 16,03 & 0,0365 \\
\hline 5 & 50,94 & 0,0444 \\
\hline 6 & 62,14 & 0,0478 \\
\hline 7 & 153,20 & 0,0433 \\
\hline 8 & 341,20 & 0,0428 \\
\hline
\end{tabular}

Source: own possessing according annual report SPP 2017 


\section{I mpact of the PR - SR gas pipeline on the final price for households}

In this part of the article we calculate the fee, which is Eustream, a.s. Justified to include in the final price for gas transportation according to a decision issued by the URSO on 17.08.2017 and which will directly reflect the relatively increased degree of security achieved by the introduction of the PR - SR. The charging of these fee in the structure of the price is possible only in one from these dates, 01.01 .2021 or the day of beginning of operation the PR - SR gas pipeline.

The Decision also sets out the exact method of calculating this charge, in which it is necessary to determine the rate in all tariffs according to the statutory coefficient to all categories of customers: wholesalers, medium subscribers, retail customers and vulnerable customers, i.e. households. For the purposes of this article, we will calculate the coefficients only in the household sector.

\subsection{Calculation of the charge rate}

Indicator for setting the fee rate for increasing the level of security of gas supply for 2021:

$$
\operatorname{SOS}(2021)=0.08 * \operatorname{HICP}(2019) / \operatorname{HICP}(2016),
$$

Where:

SOS (2021) - Charging rate to increase the level of security of gas supply for 2021,

HICP (2019) - inflation index in the European Union published by Eurostat, 2019,

Item "HICP - annual average index 1 - European Union", valid for the calendar year

HICP (2016) - inflation index in the European Union published by Eurostat,

Item "HICP - annual average index 2 - European Union" valid for the calendar year 2016.

After calculating the security charge level, a fee for each customer group is still required. This is derived from the following formula:

$$
\operatorname{PSOS}(\mathrm{t})=\operatorname{SOS}(\mathrm{t}) * \operatorname{CSOS}(\mathrm{t})
$$

Where:

SOS (t) - charge rate to increase the level of security of gas supply,

CSOS ( $t$ ) - assigned shipping capacity expressed in MWh. For capacity allocation under SOS contracts $(\mathrm{t})$, it represents the maximum number of MWh that a network user can carry on that day.

Depending on the above relationships, the RONI sets the maximum level of price increases for individual groups of vulnerable customers based on current prices and the current use of capacities in Home Point as follows. Tariffs of group 7.8 is not set, because it is no longer regulated, so we do not include them into our calculation. 
Table 3 Charges related to increased security of gas supply

\begin{tabular}{|c|c|c|}
\hline Tariff & $\begin{array}{c}\text { Average year consumption } \\
\mathrm{m}^{3}\end{array}$ & $\begin{array}{c}\text { Impact on annual gas pay- } \\
\text { ment (increased payment } \\
\text { due to increased security }\end{array}$ \\
\hline 1 & 100 & $\mathbf{+ 0 , 1 2} \boldsymbol{\mathbf { 0 }}$ \\
\hline 2 & 950 & $\mathbf{+ 0 , 8 1 €}$ \\
\hline 3 & 2850 & $\mathbf{+ 2 , 4 4} \boldsymbol{\mathbf { 2 }}$ \\
\hline 4 & 5250 & $\mathbf{+ 4 , 4 9} €$ \\
\hline 5 & 7226 & $\mathbf{+ 6 , 1 8} \boldsymbol{\mathbf { 7 }}$ \\
\hline 6 & 8653 & $\mathbf{+ 4 0} \boldsymbol{\mathbf { 7 }}$ \\
\hline
\end{tabular}

Source: own processing according: RONI Decision, 17.08.2017.

In compliance with all the above information, including the regulated, unregulated components and current charges, we will present in next table the current maximum prices set by RONI, which are binding on the target household group from 01.01.2017.

\section{Conclusion}

In the last decade the natural gas has come to the forefront due to its more environmentally friendly features. The reason is the countries are trying to ensure a smooth flow of this commodity into their territory. As the history of gas crises shows us, it is important for the importing country to have multiple sources of gas. Nowadays, the country's energy policy is oriented towards improving existing transport routes as well as planning projects that would allow for new connections with countries with adequate gas reserves. One of such solutions for Slovakia is the PL - SR gas pipeline, which is integrated into NSI East projects aimed at connecting Central and Southeast Europe. After its implementation, the Baltic Sea's connection with the Aegean, Adriatic, Mediterranean and Black Seas would be achieved, which would bring stability to the supply of the raw material for this area. Based on the decision of RONI for the Eustream, a. s. we derived the amount of the fee for individual tariffs in which households are reallocated according to natural gas consumption. In conclusion we can state, the construction of the PL - SR gas pipeline will, on the one hand, increase the level of safety for the customers of both countries but, on the other hand, a new fee will be included to the final gas price, reflecting the increase in safety.

\section{References}

Baláž, P., Ružeková, V., Svobodová, V., Perényiová, A., Pullmanová, T., Gaval'ová, V., et al. (2009). Ekonomické aspekty novej energetickej politiky EÚ a jej vplyv na strategické rozvojové zámery SR s ohladom na lisabonskú agendu. Bratislava: Vydavatel'stvo EKONÓM. 
Baláž, P., Margan, F., Ružeková, V., \& Zábojník, S. (2011). Energetická bezpečnost'v období globalizácie a jej vplyv na konkurencieschopnost' EU. Bratislava: Sprint dva.

Bahgat, G. (Ed.). (2011). Energy security: an interdisciplinary approach. John Wiley \& Sons.

Duleba, A. (2009). Poučenia z plynovej krízy v januári 2009. Analýza príčin vzniku, pravdepodobnosti opakovania a návrhy opatrení na zvýšenie energetickej bezpečnosti SR v oblasti dodávok zemného plynu. Analýzy, VÝSKUMNÉ CENTRUM SFPA, NO Bratislava, 18.

Icis Heren. (2008, July). European Gas Market:"Focus on cushion gas in storage". Retrieved September 13, 2018, from https://www.icis.com/explore/resources/news/2008/07/17/9305447/focus-on-cushion-gas-in-storage/.

Gloystein, H. (2017). Q\&A: What is a gas trading hub, and how are they established? Retrieved September 10, 2018, from https://www.reuters.com/article/us-chinagas-exchange-q-a/qa-what-is-a-gas-trading-hub-and-how-are-they-establishedidUSKBN1ENOI1.

Heather, P. (2012). Continental European gas hubs: Are they fit for purpose?.

Jambor, E. (2009). Hodnotenie energetickej politiky Slovenskej republiky v oblasti ropy a zemného plynu. Diplomová práca. Masarykova univerzita, Fakulta sociálních studií Brno.

McSweeney, B. (1996). Identity and security: Buzan and the Copenhagen school. Review of international studies, 22(1), 81-93.

Polkinghorne, M. A. (2014). Take-or-pay conditions in gas supply agreements. Oil, Gas \& Energy Law Journal (OGEL), 12(4).

Rosecrance, R., \& Stein, A. (1973). Interdependence: Myth or Reality?. World Politics, 26(1), 1-27.

Stringer, K. D. (2008). Energy security: applying a portfolio approach. Baltic security \& defence review, 10(1), 121-142.

Wigand, F. (2013, March). GG2022 - Connecting Systems: EU's Internal Energy Market and Future Cooperation with MENA. Global Policy Journal, s. 44. Retrieved August 6, 2018, from https://www.globalpolicyjournal.com/blog/13/03/2013/gg2022-connecting-systems-eu\%E2\%80\%99s-internalenergy-market-and-future-cooperation-mena

Yergin, D., \& Hillenbrand, M. (1982). Global insecurity: a strategy for energy and economic renewal.

Yergin, D. (2006). Ensuring Energy Security. Foreign Affairs, 85(2), 69-82. doi: $10.2307 / 20031912$.

Igu. (2018). Natural Gas Facts \& Figures, Market, Market Players. Retrieved August 7, 2018, from https://www.igu.org/resources-data.

Oecd/Iea. (2017). World Energy Outlook 2017. Retrieved August 10, 2018, from https://www.slideshare.net/internationalenergyagency/world-energy-outlook2017-82032554.

Eurostat. (2017). Štatistika cien zemného plynu. Retrieved August 4, 2018, from https://ec.europa.eu/eurostat/statistics-

explained/index.php?title=Natural_gas_price_statistics/sk. 
Teraz. (2014). R. Fico s V. Orbánom otvorili prepojenie sietí plynovodov. Retrieved August 14, 2018, from https://www2.teraz.sk/ekonomika/fico-orban-madarsko-plynovod/79171-clanok.html

Energia. (2017). Plynovod Eastring nevylučuje ani Mad'arsko. Retrieved August 18, 2018, from http://energia.sk/dolezite/zemny-plyn-a-ropa/plynovod-eastring-nevylucuje-ani-madarsko/25224/

Enviroportal. (2016). Prepojovací plynovod pol'sko - Slovensko. Záverečné stanovisko, Retrieved August 14, 2018, from http://www.enviroportal.sk/sk_SK/eia/detail/prepojovaci-plynovod-polsko-slovensko

Gaz-system. (2014). Interkonektor Polska - Słowacja - Gaz System. Retrieved August 21, 2018, from http://www.gaz-system.pl/fileadmin/pliki/do_pobrania/ulotka_PLSK.pdf

Eustream. (2017). Agentúra EÚ, GAZ-SYSTEM a Eustream podpísali grantovú dohodu na stavebné práce pre Prepojovací plynovod Pol'sko - Slovensko (projekt spoločného záujmu pre EÚ). Retrieved August 19, 2018, from https://www.eustream.sk/sk_media/sk_aktuality/agentura-eu-gaz-system-a-eustream-podpisaligrantovu-dohodu-na-stavebne-prace-pre-prepojovaci-plynovod-posko--slovenskoprojekt-spolocneho-zaujmu-pre-eu 